Karol Kuźmicz

Uniwersytet w Białymstoku e-mail:k.kuzmicz@uwb.edu.pl telefon: +48 857457153

DOI: $10.15290 / \mathrm{mhi} \cdot 2016.15 .02 .16$

\title{
Francuskie utopie oświeceniowe jako wyraz kultury politycznej i prawnej swoich czasów
}

\author{
SUMMARY \\ French Utopias of Enlightenment as a Manifestation of Political and Legal culture \\ of this Time
}

The author presents the impact of Utopian thought on the French political and legal culture during the Age of Enlightenment. Contemporary Utopias were the ideological background of the French Revolution. The machinations of $18^{\text {th }}$ century France aside, we can call this time the "Age of Utopia". This is confirmed by the studies of many French scholars and researchers. Professor Bronisław Baczko, a Polish philosopher and historian, also presented this view in his work: "Utopian Lights: The Evolution of the Idea of Social Progress" (English Edition: New York 1989). It should be noted that the Enlightenment Utopias were concentrating on the nature of man and his social, economic, political and legal life. The texts of Utopians were also associated with philosophy and literature. They challenged the old order: Feudalism and Absolutism. In this way, the Utopias were the ideological weapon in the fight for a better world, that could only be redeemed by the Revolution.

Key words: Enlightenment, natural law, revolution, legal culture, political culture.

Słowa kluczowe: Oświecenie, prawo natury, rewolucja, kultura prawna, kultura polityczna.

\section{Wprowadzenie}

Od momentu pojawienia się pierwszej renesansowej utopii społecznej Tomasza Morusa można mówić o początkach przeobrażania nowożytnego świata zgodnie z zasadami rozumu i natury, a więc zasadami, w oparciu o które utopie powstawały oraz funkcjonowały. Z jednej strony utopie od początku wpisywały się w klimat swojej epoki, wywierając silny wpływ na kulturę polityczną i prawną swoich czasów. Z drugiej zaś strony wykraczały daleko poza swoje czasy, przyczyniając się do kształtowania kultury politycznej i prawnej epok następnych. 
Tak właśnie było z utopiami renesansowymi i oświeceniowymi, charakter taki wywierał również socjalizm utopijny, obecnie dzieje się tak z coraz popularniejszymi antyutopiami, które wszystkie razem składają się na pojęcie utopizm $^{1}$, przyczyniając się przede wszystkim do intelektualnej dyskusji na temat życia społecznego ludzi i jego niedoskonałości. Problemy tego świata utopiści na pewno trafnie diagnozowali, ale nie zawsze potrafili podać skuteczne metody ich rozwiązywania. $W$ świecie realnym proponowane przez nich rozwiązania zazwyczaj nie sprawdzały się, ponosiły klęskę potwierdzając, że to, co teoretycznie jest możliwe, w praktyce nie zawsze ma jednak sens. Współcześnie choć utopizm jest różnie oceniany i postrzegany, to od początku ma jeden obiektywny walor związany ze swoją genezą o charakterze literackim. Jest to gatunek (utwór)² pozwalający swojemu autorowi dokonywać krytyki rzeczywistości, z którą nie może się pogodzić, tworząc dla niego alternatywę. Filozoficzne przesłanki utopizmu nadają mu wymiar ponadczasowy i uniwersalny. Przesłanie wszystkich utopii jest identyczne, każdy człowiek chce być szczęśliwy żyjąc pośród innych ludzi, którzy mają takie samo prawo do szczęścia ${ }^{3}$. Utopie zakładają przy tym, że da się pogodzić szczęście indywidualne każdego człowieka z interesem wspólnoty, którą tworzą. Na tym ma właśnie polegać doskonałość świata utopijnego. Francuscy myśliciele epoki Oświecenia domagali się właśnie szczęścia, zarówno indywidualnego, jak i zbiorowego ludzi,

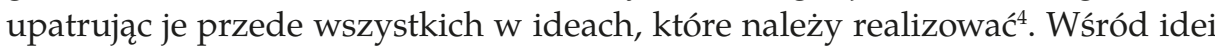
tych najczęściej wskazywano na mające zagwarantować im szczęście, czyli: społeczną sprawiedliwość, wolność, równość, braterstwo i solidarność. Na pytanie czy idee wywołały rewolucję? - odpowiedzi specjalistów są do dziś podzielone. Dla jednych od początku ,były to idee buntownicze w stosunku do przeszłości, pełne zaś optymizmu co do przyszłości" ${ }^{5}$. Z kolei dla innych, choć „wiek Oświecenia nigdy nie wzywał do rewolty to trzeba jednak uznać, że w dużej mierze uczestniczył w przygotowaniu opinii akceptującej Rewolucję" ${ }^{\prime 6}$. W obu przypadkach utopie stanowiły przede wszystkim „intelektualną przestrzeń”, w której toczyła się teoretyczna i polityczna [praktyczna - podkr. K. K.] walka między najważniejszymi wartościami ${ }^{7}$. Utopie będące bowiem „wytworem spekulatywizmu intelektualistów (...) od Rewolucji Francuskiej przenikają do polityki"8,

Zob. Ł. Stefaniak, Utopizm: źródła myślowe i konsekwencje cywilizacyjne, Lublin 2011, s. 59-61.

M. M. Leś, Fantastyka socjologiczna, Poetyka i myślenie utopijne, Białystok 2008, s. 11.

Zob. W. Tatarkiewicz, O szczęściu, Warszawa 2010, s. 410 i nast.

$4 \quad$ Por. G. Farrugia, Qu'écrire sur le bonheur au XVIIIe siècle après Robert Mauzi? [w:] Le bonheur au XVIIIe siècle, red. G. Farrugia, M. Delon, Rennes 2015, s. 13; www.pur-editions.fr (10.10.2016).

G. L. Seidler, Przedmarksowska myśl polityczna, Kraków 1974, 1985, s. 547.

6 M. Morabito, D. Bourmaud, Historia konstytucyjna i polityczna Francji (1789-1958), tłum. A. Jamróz, Białystok 1996, s. 47.

Por. R.-M. Allemand, L'utopie, Paris 2005, s. 17.

$8 \quad$ R. Tokarczyk, Paradygmat utopizmu w zmaganiach z paradygmatem realizmu, [w:] Oblicza utopii, obłudy i zakłamania I, red. W. Łysiak, Poznań 2013, s. 25 i 26. 
wcześniej bardziej niż z polityką, wiązały się jednak z filozofią i literaturą ${ }^{9}$. Jak zauważył Jan Baszkiewicz, późniejsza „literackość” samej rewolucji stała się narzędziem walki i pedagogiki politycznej, przy tym narzędziem „piekielnie ostrym i niebezpiecznym dla tych, którzy się nim posługiwali"10.

\section{Wpływ filozofii na kulturę polityczną i prawną czasów Oświecenia}

Bronisław Baczko uważał natomiast, że utopie „powieściowe”, które są przede wszystkim „zabawami intelektualnymi” mają pobudzać wyobraźnię oraz krytyczną i moralizującą refleksję czytelników ${ }^{11}$. Według niego „utopia chce osadzić rozum w sferze wyobraźni. W utopiach odbywa się nieustanna wymiana między marzeniami społecznymi a krytyczną, teoretyczną, normatywną itd. refleksją nad życie społecznym"12. Z tego względu autorzy utopii byli zazwyczaj filozofami wybierającymi bardzo często formę literacką do wyrażania swoich poglądów albo literatami poruszającymi w swoich utworach problemy stricte filozoficzne. W epoce Oświecenia takie podejście było wręcz modne. Powstające wówczas teksty miały być nie tylko piękne pod względem artystycznym, ale także mądre w sensie filozoficznym. Wynika $z$ tego, że podejmowano się zadania trudnego, a przy tym wzniosłego, ponieważ chciano spopularyzować refleksję filozoficzną jako bardziej dostępną i zrozumiałą dla czytelnika, który nie był filozofem. Stworzono więc wzorcowy model utopisty jako „marzyciela politycznego" tworzącego „powieści polityczne”, a w nich „chimeryczne” projekty prawodawstwa doskonałego ${ }^{13}$. W powyższym kontekście „Filozof” określa pewną postawę społeczną, jego zaangażowanie się, znajdujące wyraz przede wszystkim w twórczości literackiej, zajmującej jednoznaczne pozycje w walce idei $^{14}$. Tak ujmowana postawa filozofa wiąże go z poczuciem niezależności, której sam coraz bardziej się domaga, następnie z poczuciem misji doskonalenia człowieka i otaczającego go świata, co z kolei wiąże go z koniecznością nie tylko teoretyzowania, ale także praktycznego zaangażowania. Poza tym oświeceniowy „Filozof”, jak nigdy wcześniej odwołuje się do opinii publicznej, której

9 Por. K. Kuźmicz, Utopia jako metoda filozofowania o społeczeństwie, państwie, prawie. Krótka analiza badawcza, [w:] Myślenie o polityce i prawie. Przedmiot, metoda, praktyka, red. I. Barwicka-Tylek, A. Czarnecka, M. Jaskólski, J. Malczewski, Warszawa 2015, s. 258.

$10 \quad$ J. Baszkiewicz, Wolność. Równość. Własność. Rewolucje burżuazyjne, Warszawa 1981, s. 272.

11 B. Baczko, Światła utopii, tłum. W. Dłuski, Warszawa 2016, s. 40.

12 Ibidem, s. 38.

13 Ibidem, s. 47.

14 Idem, Wstęp, [w:] Filozofia francuskiego Oświecenia. Wybrane teksty z historii filozofii, wyboru dokonał oraz wstępem i przypisami opatrzył B. Baczko, Warszawa 1961, s. 10. 
uważa się za rzecznika - najczęściej postępu i ludu oraz wszelkich idei społecznych podważających zasadność dotychczasowego ustroju ${ }^{15}$.

Filozofowie-utopiści nie tworzyli swoich systemów jako jedynie apriorycznych i zupełnie oderwanych od rzeczywistości, a sposoby ujmowania przez nich człowieka, natury, sprawiedliwości i rozumu, równości politycznej i społecznej były przy tym konstrukcjami wyraźnie powiązanymi z dawnymi teoriami czy realizmem politycznym ${ }^{16}$. Spośród wskazanych powyżej, ściśle ze sobą powiązanych elementów, filozofia oświecenia wybrała zasadniczo dwa najważniejsze, określając je skrótowo mianem: „natura i rozum" ${ }^{17}$. Elementy te stanowiły również fundament ówczesnego myślenia utopijnego, zwłaszcza dla podejmujących walkę ze starym porządkiem i pragnących zbudować nowy i bardziej sprawiedliwy świat niż ten, w którym przyszło im żyć1 ${ }^{18}$. Estetyczny wymiar utopii przedrewolucyjnych uznawał rozum za źródło społecznego postępu i nowości, które nie były jeszcze zinstytucjonalizowane ${ }^{19}$. Utopie dawały jednak nadzieję na to, że świat może być lepszy niż jest, a życie w nim, zwłaszcza życie społeczne ludzi, można tak zaplanować i zorganizować, żeby takim właśnie się stało ${ }^{20}$.

Oceniając klimat epoki, w którym przyszło żyć i tworzyć wspomnianym myślicielom na pierwszym miejscu należy wymienić fakt dziejowego znaczenia XVIII w. i francuskiego Oświecenia, który dla nas współczesnych jest przede wszystkim epoką przedrewolucyjną. „Filozofia (...) pełni w niej rolę hegemoniczną. Jest to wiek filozoficzny. Filozoficzna jest literatura i sztuka tej epoki, historia i ekonomia, traktaty i pamflety polityczne - a sama filozofia nie omija żadnej dziedziny twórczości intelektualnej, posługuje się wszelkimi gatunkami literackimi, od rozprawy i traktatu do tragedii i powiastki filozoficznej"21.

Francja w Europie od czasów panowania Ludwika XIV jawi się również jako hegemon stylu życia, głównie przez „promieniowanie” swojej kultury, a nade wszystko języka ${ }^{22}$. „Można było mówić o «francuskiej Europie wieku Oświecenia» (Réau) przede wszystkim z racji ogromnego zasięgu języka francuskiego, który od r. 1713 stał się jedynym językiem dyplomatycznym, a także mową wszystkich wyższych sfer społecznych"23. Francuska przewaga była rów-

\footnotetext{
Ibidem, s. 15.

16 Por. Ch. Rihs, Les philosophes utopistes: le mythe de la cité communautaire en France au XVIIIe siècle, Paris 1970, s. 241.

17 Por. G. L. Seidler, op. cit., s. 547.

18 Ibidem.

19 Por. P. Francastel, L'esthétique des Lumières, [w:] Utopies et institutions au XVIIIe siècle. Le Pragmatisme des Lumières, Congrès et Colloques IV, Paris 1963, s. 352.

20 Por. S. Drelich, Utopie jako nadzieja. Najważniejsze założenia koncepcji utopijnych starożytności i odrodzenia, „Dialogi Polityczne” 2003, nr 1, s. 12.

21 B. Baczko, Wstęp, [w:] Filozofia francuskiego..., s. 8-9.

22 Por. É. Perroy, R. Doucet, A. Latreille, Historia Francji, t. 1: Od początku dziejów do roku 1774, tłum. A. Łochocka, Warszawa 1969, s. 564-566.

23 Ibidem, s. 565. Zob. także: L. Réau, L’Europe française au siècle des lumières, Paris 1971, s. 438; (L’Evolution de l'humanité), t. 80 .
} 
nież zauważalna na gruncie intelektualnym, zwłaszcza w filozofii, która już od czasów Kartezjusza (1596-1650) eksponowała rolę rozumu i jego idei, w tym coraz częściej idei politycznych. Swoją dominującą pozycję ówczesna Francja, jak widać budowała racjonalnie, a więc opierając się na planach realizowanych następnie w różnych sferach życia, począwszy od życia intelektualnego poprzez gospodarkę, sztukę, a nawet modę. Francuzi robili to zatem metodycznie i dzięki temu skutecznie.

Na rozwój francuskiej myśli utopijnej XVIII w., bez wątpienia przeogromny wpływ wywarły wcześniejsze, czyli XVII-wieczne teksty utopijne, które stanowiły zapowiedź nadchodzącego dopiero "gorącego okresu w dziejach utopii”24. Tak właśnie czasy francuskiego Oświecenia jako „epoki, która sama siebie określa za pomocą symboliki światła" nazwał znakomity badacz tematu Bronisław Baczko ${ }^{25}$. Jak z kolei podaje Henri Desroche, tytuł dzieła Baczki jest celowo dwuznaczny: Lumières de l'Utopie (Światła utopii) i odnosi do oświeceniowych utopii jako świateł tej epoki ${ }^{26}$. Utopie bowiem niczym gwiazdy, czy też ogień - zarazem rozświetlały i ogrzewały. Problemem w dyskursie utopijnym, na który badacz ten zwrócił baczną uwagę w kontekście późniejszego terroru rewolucyjnego oraz totalitaryzmów jest jednak fakt, że treści utopijne, jednym w mrocznych i burzliwych czasach drogę życiową rozświetlały, innych niestety zaślepiały ${ }^{27}$. „Utopie stanowią przede wszystkim cenne świadectwo niepokojów, nadziei i obsesji swojego czasu"28. W powyższym kontekście, były one utożsamiane z ciepłem jaki daje ogień - jednych w trudnych czasach ogrzewały, niosąc zapewne nadzieję na lepsze czasy i pomagały przetrwać, innych zaś dosłownie spopielały, siejąc „,nie tylko terror, ale także zgrozę ${ }^{\prime 29}$. Ten tragiczny wymiar rewolucji francuskiej obrazowo podsumował Aleksander Świętochowski, pisząc o tym, że: „Wulkan Rewolucji wyrzucał swą lawę i zalewał wszystko”"30.

Wykorzystując w dalszym ciągu grę słów zaproponowaną przez Bronisława Baczkę, w ujęciu dużo bardziej optymistycznym można jednak dodać, że utopie nie tylko oświecały, czy otępiały umysły ludzkie, ale przede wszystkim uświetniały nadając wzniosłość, co należy odnieść do całej epoki Oświecenia i jej znaczenia w dziejach Francji, a nawet ludzkości, zwłaszcza jeśli spojrzymy na te światła z perspektywy dziejowej, w tym historiozoficznej.

24 Zob. wydanie francuskie: B. Baczko, Lumières de l'Utopie, Paris 1978, s. 37. Tak jak Oświecenie Bronisław Baczko nazywał "gorącym”, tak współczesność „zimnym” okresem dla utopii; zob. idem, Wyobrażenia społeczne. Szkice o nadziei i pamięci zbiorowej, tłum. M. Kowalska, Warszawa 1994, s. 54 i 156.

25 Zob. B. Baczko, Światła utopii, s. 16.

26 Por. H. Desroche, Baczko (Bronislaw): Lumières de l'Utopie, "Archives de Sciences Sociales des Religions" 1979, nr 47/2, s. 225-226.

27 Por. B. Baczko, Wyobrażenia..., s. 135-157.

28 Ibidem, s. 114.

29 Są to słowa wypowiedziane przez Pierre'a Chaux, podczas procesu Komitetu Rewolucyjnego; cyt. za: B. Baczko, Jak woyjść z terroru. Termidor a Rewolucja, tłum. W. Dłuski, Gdańsk 2005, s. 157.

30 A. Świętochowski, Utopie w rozwoju historycznym, Warszawa 1910, s. 104. 
Wśród XVI-wiecznych dzieł utopijnych poprzedzających dynamiczny rozwój utopizmu francuskiego czasów Oświecenia należy wskazać przede wszystkim na: Histoire des Sévarambes - Denisa Vairasse'a (1630-1672), opublikowane po raz pierwszy w Londynie po jego śmierci w 1675 r. Następnie na dwie bardzo ważne dla rozwoju gatunku powieści podróżnicze: La Terre Australe connue z 1676 r., Gabriela de Foigny (1630-1692) oraz Les Aventures de Télémaque z 1699 r., których autorem był duchowny François de Selignac de la Monthe Fénelon (1651-1715) ${ }^{31}$. Ten ostatni w swoim Liście do Ludwika XIV z końca 1693 r., przestrzegał króla na 100 lat przed faktycznym upadkiem monarchii francuskiej, uznając absolutne sprawowanie władzy za "śmiertelne niebezpieczeństwo" ${ }^{\prime 32}$, które groziło zarówno jemu jako panującemu oraz państwu, z który się przecież utożsamiał, mówiąc: „L'État c'est Moi” („Państwo to Ja”). W tym kontekście nie można zapomnieć, chyba o najbardziej znanym obecnie, ale nie pochodzących z Francji dziełach opisywanego okresu, czyli: Bajek o pszczołach - Bernarda Mandeville'a ${ }^{33}$, opublikowanych pierwszy raz w 1705 roku, oraz Podróżach Guliwera - Jonathan'a Swift'a z 1726 roku $^{34}$.

Ważny element wpływający na tworzenia utopii stanowiły od początku rozwoju tego gatunku - odkrycia geograficzne, w tym udział Francji w tworzeniu własnych zamorskich kolonii. Szczególnie cenionym nie tylko przez Francuzów był podróżnik, odkrywca i oficer królewskiej floty - Loius Antoine de Bougainville (1729-1811) ${ }^{35}$. Inspirującym dla wielu utopistów okazał się jego dziennik z podróży dookoła świata z lat 1766-1769 - Voyage autour du monde par la frégate de roi La Boudeuse et la flute L'Étoile (Podróż Bougainville'a dookoła świata) ${ }^{36}$. W piśmiennictwie utopijnym „rozmnożyły się” opisy ludów pierwotnych oraz "dobrych dzikusów" z nowego świata, jak: Huronowie, Irokezi, Peruwiańczycy, Tahitańczycy i inni, których społeczności idealizowano przedstawiając najczęściej jako wzór braterstwa, prostoty i szczęścia ${ }^{37}$.

31 Nie należy mylić dzieła Fénelon'a z inną francuską powieścią pod tym samym tytułem: Przygody Telemacha napisaną przez Louis'a Aragona w 1922 r., a będącą pastiszem dadaistycznym dzieła oświeceniowego.

32 Fénelon, La Lettre à Louis XIV; zob. http://www.recherche-fenelon.com/page-12778-lettre-louism. html (21. 11. 2016).

33 W 1705 roku bajki holenderskiego pisarza wydano pod angielskim tytułem: The Grumbling Hive, or Knaves Turn'd Honest. Zob. B. Mandeville, Bajki o pszczołach, tłum. A. Glinczanka, Warszawa 1957.

$34 \quad$ Zob. J. Swift, Podróże Guliwera, oprac. z ang. C. Niewiadomska, Warszawa 1995.

35 Co ciekawe: Bougainville był z wykształcenia prawnikiem, który interesował się matematyką. Podczas wojny o niepodległość Stanów Zjednoczonych dowodził eskadrą francuskich okrętów. Natomiast w czasie rewolucji francuskiej pozostał wierny królowi Ludwikowi XVI, aresztowany w wyniku terroru jakobińskiego, cudem uniknął zgilotynowaniu. Za Napoleona Bonaparte: najpierw senator, później oficer Legii Honorowej i wreszcie przewodniczący francuskiej Rady Wojennej jako Najwyższego Trybunału Wojskowego. Od 1811 r., jego ciało spoczywa w katakumbach paryskiego Panteonu.

36 Zob. L. A. Bougainville, Podróż Bougainville'a dookoła świata, tłum. L. Szwykowski i M. Szwykowska, Warszawa 1962.

37 J. Baszkiewicz, Historia Francji, Wrocław - Warszawa - Kraków 2004, s. 317. 
Z kolei do francuskich utopistów XVIII wieku, na pewno zaliczyć należy, wymieniając ich chronologicznie, a przyjmując za podstawę lata życia, takich myślicieli jak: Jean Meslier (1664-1729), Gabriel Bonnot de Mably (1709-1785), Léger Marie (Dom) Deschamps (1716-1774), Éteienne-Gabreiel Morelly (17171778), Nicolas Edme Restif de la Bretonne (1734-1806), Louis Sebastian Mercier (1740-1814), Jean Antoine Nicolas de Condorcet (1753-1794), Jacques Pierre Brissot de Warville (1754-1793) ${ }^{38}$.

Warto przy tym zaznaczyć, że wszyscy wymienieni powyżej francuscy myśliciele swoje utopijne wizje tworzyli przed wybuchem rewolucji francuskiej 1789 roku, której zdecydowana większość z nich nie doczekała. Ich poglądy o charakterze utopijnym zostały zazwyczaj wyrażone w jednym najważniejszym tekście. Wyjątek stanowi Mably, którego należy uznać za najpłodniejszego z wymienionych pisarzy politycznych, w związku z czym jego poglądy utopijne są rozproszone w kilku dziełach. Odnośnie do pisarstwa Jana Meslier'a to mamy na myśli jego - Testament, choć spisywany przed 1729 r., to opublikowanym dopiero w 1772 r.; z twórczości Étienna-Gabriela Morelly wskazujemy na Kodeks natury z 1745 r. i poprzedzającą go mało znaną w Polsce powieść utopijną Bazyliadę z 1753 r.; wśród bogatej twórczości wspomnianego Gabriela Bonnot de Mably są to, z pewnością Zasady praw z 1776 r.; u Mikołaja Edme Restifa de la Bretonne jest to powieść utopijna La Découverte australe par un homme volant, ou Le Dédale français (Odkrycie ziemi australnej przez człowieka pływajacego lub francuskiego Dedala) z 1781 r.; z kolei u Ludwika Sebastiana Mercier chodzi o nietłumaczoną na język polski nowelę z 1771 r.: L'An 2440, rêve s'il en fut jamais (Rok 2440: Marzenie jeśli kiedykolwiek jakieś było); a u Jakuba Piotra Brissot są to: Recherches philosophiques sur le droit de propriété et sur le vol considérés dans la nature (Filozoficzne poszukiwania prawa własności i grabieży zadanej naturze) z $1780 \mathrm{r}$. oraz Lettres sur la Liberté politique (Listy o wolności politycznej) z 1783 r.; natomiast u Antoniego Mikołaja de Condorcet opublikowany pośmiertnie już w trakcie rewolucji: Esquisse d'un tableau historique des progrès de l'esprit humain (Szkic obrazu postępu ducha ludzkiego poprzez dzieje).

Utopijny charakter przypisuje się, także niektórym poglądom Jana Jakuba Rousseau (1712-1778), który de facto był francuskojęzycznym Szwajcarem ${ }^{39}$. Sporadycznie wątki utopijne można również znaleźć u tak znakomitych myślicieli francuskich, jak: Monteskiusz (1689-1755), czy Wolter (1694-1778) ${ }^{40}$, a także u wielu mniej lub bardziej znanych autorów takich utopii, jak np.: Histoire de l'Ile de Caléjava ou l'Ile des Hommes raisonables z 1700 r. - Claude'a Gilbert'a (1652-1720);

$38 \quad$ Zob. Ch. Rihs, op. cit., s. 37-240.

39 Chodzi głównie o utopijne przesłanie Nowej Heloizy z 1761 r., ale także jego przewodniego hasła „powrotu do natury" oraz bezpardonowej krytyki własności prywatnej jako przyczynę moralnego zła i społecznych nieszczęść.

40 Wymienić przy tym należy opowieść o Troglodytach z Listów perskich Monteskiusza opublikowanych w 1721 r., oraz utopijne wątki związane z krainą Eldorado zawarte w najsłynniejszej powiastce filozoficznej Woltera - Kandyd, czyli optymizm z 1759 r. 
Voyages et Avantures de Jacques Massé z 1710 r. - Simon'a Tyssot de Patot (16551738); Les Femmes militaires, relation historique d'une isle nouvellement découverte z przełomu lat 1734/1735 - Louis'a Rusting'a de Saint-Jory (16??-1752); wydany w siedmiu tomach w latach 1731-1739: Le Philosophe anglais ou Histoire de M. Cleveland, fils naturel de Cromwell - Antoine'a François Prévosta (1697-1763), następnie: Giphantie z 1760 oraz Histoire naturelle, civile et politique des Galligènes z 1765 r. - Charles'a François Tiphaigne de la Roche'a (1722-1774); czy dramatów takich, jak: L'Île des elausces z 1725 r., L'Île de la raison z 1727 r., oraz La Colonie z 1750 r. - uznawanego za jednego z najwybitniejszych XVIII-wiecznych, francuskich pisarzy - Pierre'a Carlet de Chamblaine de Marivaux (1688-1763) ${ }^{41}$; dalej mamy L'Elève de la nature (Wychowańca natury) z 1763 r. - Gasparda Guillarda de Beaurieu (1728-1795) oraz Theorie des loi civiles z 1767 r. - Simon'a Nicolas'a Henri Linguet (1736-1794), tych dwóch ostatnich do tzw. „utopistów praw natury” zaliczył Aleksander Świętochowski ${ }^{42}$. Ten polski badacz zajmujący na przełomie XIX i XX w., m.in. problematyką utopii, powoływał się głównie na pracę André Lichtenbergera z 1898 r., o prekursorach socjalizmu utopijnego, wskazując dodatkowo jako francuskich utopistów czasów Oświecenia: Nicolas'a Gueudeville'a (1652-1721) oraz Charles'a-Roberta Gosselin (1740-1820) ${ }^{43}$. Na odrębną uwagę zasługuje również dzieło Bernarda le Bovier de Fontenelle'a (1657-1757) - La République des philosophes ou histoire des Ajaoiens, wydane po śmierci filozofa w $1768 \mathrm{r}$.

Istnieje jednak sporo wątpliwości, co do liczby tekstów utopijnych, jakie pojawiły we Francji w epoce Oświecenia. Gisèle Berkman zwraca uwagę na gwałtowny wzrost ich popularności w XVIII w., szacując ich liczbę na 70, w porównaniu do 8 utopii z XVII w. ${ }^{44} \mathrm{~W}$ podobnym tonie wypowiedział się Werner Krauss, według którego ówczesna „literatura utopijna rozwinęła się w sposób bezprecedensowy ${ }^{\prime \prime 5}$. Posiłkując się m.in. jego badaniami, można obliczyć, że od 1700 do 1789 roku, pojawiło się nawet od 150 do 200 takich tekstów ${ }^{46}$. Bronisław Baczko oszacował liczbę „wyobrażonych podróży” na $80^{47}$. Jednakże, jego zdaniem „im bardziej utopia się upowszechniała, im bardziej różnicują się jej formy, tym mniej wyraźne są jej granice, do tego stopnia, że rozmiary zjawiska nie dają się ująć ilościowo" ${ }^{\prime 48}$. A zatem nowatorską propozycją podejścia do problematyki utopii może okazać się, próba ich przeanalizowania w kontekście pojęcia prawa, w tym przypisywanej mu przez utopistów roli, jego znaczenia,

\footnotetext{
${ }_{41} \quad$ Zob. R.-M. Allemand, op. cit., s. 121-130.

42 Zob. A. Świętochowski, op. cit., s. 90-106.

43 Zob. A. Lichtenberger, Le socialisme utopique: études sur quelques précurseurs inconnus de socialisme, Genève 1978 .

44 M. Riot, T-Sarcey. Bouchet et A. Picon, Dictionnaire des utopies, Paris 2002, s. 106.

45 Zob. W. Krauss, Reise nach Utopia, Berlin 1964; cyt. za: B. Baczko, Światła utopii, s. 54.

46 Por. H. Desroche, op. cit., s. 225.

$47 \quad$ B. Baczko, Światła utopii, s. 54.

$48 \quad$ Ibidem, s. 58-59.
} 
a zwłaszcza sposobów stanowienia i obowiązywania. W pewnym sensie będzie to stanowiło ujęcie jakościowe tych utopii, które w różnorodny sposób podchodziły do zagadnienia prawa.

\section{Idealizowanie i kult prawa}

Wszyscy utopiści byli ludźmi dobrze znającymi realia społeczne, których cechował realizm i wyobraźnia socjologiczna ${ }^{49}$. Wielu badaczy utopii podkreśla, że z filozoficznego punktu widzenia, elementem najważniejszym w literaturze utopijnej jest krytyka rzeczywistości społecznej i politycznej ${ }^{50}$. Francuscy utopiści oświeceniowi „krytycznie zatem oceniali stan stosunków międzyludzkich i charakter człowieka we Francji w wieku XVIII, winą za to obarczali panujące we Francji stosunki społeczno-polityczne, w szczególności zaś panujący ustrój polityczny i absolutyzm monarchów, zagradzający drogę postępowi i ukształtowaniu stosunków społecznych zgodnych z naturą człowieka" ${ }^{\prime 51}$. Jak podaje Rajmund Ruyer krytyka ta może mieć charakter konstruktywny, zwłaszcza wtedy, gdy wiąże się z projektami ustaw i konstytucji ${ }^{52}$. Właśnie krytyczne i konstruktywne zarazem podejście do prawa zaobserwować możemy analizując myśl francuskich utopistów czasów Oświecenia.

Należy przy tym zaznaczyć, że „każda krytyka dokonywana jest z punktu widzenia ideału (...) - wszak i prezentacja ideału jest potencjalna krytykę"53. Krytyczny charakter ma, także nauka oparta na prawie naturalnym ${ }^{54}$. Prawie, które przyjmuje się, że jest doskonałe, gdyż odzwierciedla najpełniej ideał sprawiedliwości, stanowiąc wzorzec dla praw stanowionych przez człowieka. Praw ludzkich, które doskonałe nie są, choć mogą takie być, jeśli będą zgodne z prawem natury. Dla utopistów „człowiek konkretny to zespół praw, które jako «naturalne» tożsame są z jego istotą i są wyrazem równości ludzi. O ile dla tradycyjnego światopoglądu znamienne jest wyrażanie stosunków między jednostką a społeczeństwem w kategorii powinności i przywileju, o tyle w oświeceniowym światopoglądzie wyrażane są one w kategorii prawa (...) $)^{\prime \prime 55}$. Z tego względu, „człowiek i obywatel XVIII wieku to uniwersalny, ponadnarodowy model wroga wszelkiej tyranii i obrońcy prawd ludzkich (...), do których kluczem może być tylko rozum" ${ }^{\prime 56}$.

\footnotetext{
49 I. Pańków, Filozofia utopii, Warszawa 1990, s. 171.

50 R. Ruyer, L'Utopie et les utopies, Paris 1950, s. 6-7; T. Molnar, L'Utopie: éternelle hérésie, tłum. z ang. O. Launay, Paris 1967, s. 17; I. Pańków, op. cit., s. 171.

51 L. Zdybel, J. Malarczyk, Historia doktryn polityczno-prawnych, Lublin 2001, s. 206.

52 R. Ruyer, op. cit., s. 7.

53 I. Pańków, op. cit., s. 173.

54 Por. J. Hervada, Prawo naturalne. Wprowadzenie, tłum. A. Dorabialska, Kraków 2011, s. 175.

55 B. Baczko, Wstęp, [w:] Filozofia francuskiego..., op. cit., s. 51.

56 J. Baszkiewicz, F. Ryszka, Historia doktryn politycznych i prawnych, Warszawa 1979, s. 236.
} 
A zatem francuskie utopie oświeceniowe wynosiły na piedestał wszystko to, co rozumne, w tym także prawo, a w szczególności prawo natury, które uważano nie tylko za przejaw racjonalizmu, ale także sprawiedliwości, ładu, porządku i harmonii, czyli stanu, do którego należy dążyć, a jeśli to możliwe to stan taki przywrócić. Hasła powrotu do natury i jej praw oraz racjonalizacji prawa miały nadawać inny, niż dotychczas, czyli prawidłowy charakter życiu społecznemu ludzi. Sama bowiem natura była dla nich rzeczywistością podlegającą obiektywnym prawom, a działający pod wpływem naturalnych instynktów człowiek - częścią tej natury ${ }^{57}$. Dominujący w XVIII-wiecznej filozofii obraz natury jako doskonale funkcjonującego systemu nie zawierał $\mathrm{w}$ sobie nic tajemniczego ${ }^{58}$. Choć z jednej strony obraz ten był „pompatyczny”, wręcz „nadęty”, gdyż opiewał wyłącznie zalety natury, z drugiej zaś strony był „prosty” i szczery w swoim przesłaniu ${ }^{59}$, przez co zrozumiały i dostępny dla tych wszystkich, którzy zdecydowali się „mieć odwagę korzystać ze swego rozumu”60.

Pod wieloma względami przypominało to bardzo sposób myślenia o naturze stoików, według których życie rozumne to życie zgodne z naturą jako prawami kosmosu ${ }^{61}$. Takie życie było przy tym moralne, gdyż opierało się na podstawie wiecznych, niezmiennych i doskonałych praw, których przestrzeganie zapewnić ma szczęście. Można zatem zgodzić się z Ugo Bellagambą, że ówczesne utopie miały przy tym najbardziej normatywny charakter ze wszystkich znanych utopii, ponieważ od początku były inspirowane przez naturę i jej uniwersalne prawa $^{62}$.

Poza tym prawo w utopiach było elementem pozwalającym nadawać realny sens ideom w nich zawartych. Utopiści traktowali zatem prawo jako pomost łączący to wszystko, co jest idealne, a zarazem nieosiągalne, $\mathrm{z}$ tym, co realne i możliwe. W rezultacie, ujmowane w ten sposób prawo, które do tej pory obowiązywało i w zasadzie zniewalało ludzi, obciążano głównie moralną odpowiedzialnością za społeczną niesprawiedliwość i zło. Z drugiej zaś strony zakładano, że odwołując się do natury i jej praw stworzy się sprawiedliwszy porządek prawny, który wyzwoli wszystkich ludzi eliminując owe zło. Ponieważ prawo, zwłaszcza te, które powinno faktycznie obowiązywać było wtedy utożsamiane $\mathrm{z}$ prawem natury, to znajdowało swe miejsce jedynie $\mathrm{w}$ ramach nauki o moralności, stanowiącej część oświeceniowej filozofii moralnej ${ }^{63}$. Łączone w ten

\footnotetext{
G. L. Seidler, op. cit., s. 547.

58 A. Le Flamanc, Les utopies prérévolutionnaires et la philosophie du 18e siècle, Paris 1934, s. 44.

59 Por. ibidem.

60 Hasło Oświecenia według Immanuela Kanta brzmiało: SAPERE AUDE! [w:] Co to jest Oświecenie?; zob. termin: idéal de Lumières, w opracowaniu Gisèle Berkman, [w:] Dictionnaire des utopies, s. 106-108.

61 Por. A. Le Flamanc, op. cit., s. 31 i nast.

62 U. Bellagamba, Loi, [w:] Dictionnaire critique de l'utopie au temps des Lumières, red. B. Baczko, M. Porret, F. Rosset, Chêne-Bourg 2016, s. 708.

63 Por. W. Wołodkiewicz, Uwagi na temat prawoznawstwa w filozofii wieku Oświecenia, [w:] Filozofia Marii Szyszkowskiej. Księga dedykowana, red. A. Kryniecka, Białystok 2012, s. 326.
} 
sposób prawo i moralność znajdowały się w służbie doskonałości ${ }^{64}$, do której należało dążyć przez wcielanie w życie konkretnych ideałów.

Warto przy tym zaznaczyć, iż w praktyce społecznej utopijne założenia wcielane w życie wywierały bardzo często katastrofalne skutki. Błędnie zakładano, że winni są temu ludzie, których masowo mordowano, poświęcając w imię wyższych wartości, których nigdy nie osiągano. Najlepsze nawet prawo, ucieleśniające ideały, nie jest zatem warunkiem wystarczającym, ale koniecznym do tego, by naprawiać ten świat. Nasuwa się zatem pytanie, po co to wszystko robić? A mianowicie dlatego, że człowiek jest odpowiedzialny za swój los, za każde dobro i zło, które wyrządza innym. Choć sam wie, że ze swej natury jest niedoskonały i pełen wad, to jednak może się rozwijać dzięki postępowi w rozmaitych dziedzinach. Postęp ten dotyczy także prawa i jego instytucji, które wciąż zmieniają się dążąc do doskonałości. Po jej osiągnięciu nowy system prawa zostanie jednak zamknięty. Działanie takie według Pierre'a-François Morreau odgrywa podwójną rolę, czyli ma nie dopuścić do zmian i pogardy orzecznictwa, które przyniesie rewolucja oraz pozwolić na przysługiwanie każdemu jego praw ${ }^{65}$. W rezultacie będzie się to wiązać z rozszerzeniem kontroli prawnej zjawisk społecznych przez: zwięzłość, jasność i prostotę obowiązującego prawa oraz nadanie mu powszechnego i podniosłego charakteru ${ }^{66}$. W ten sposób wzmocni się nie tylko zaufanie do samego prawa, ale także świadomość prawną jednostek, znających swoje prawa i obowiązki ${ }^{67}$.

\section{Znaczenie i przesłanie utopii}

A zatem utopie były odpowiedzią intelektualistów czasów Oświecenia na problemy świata, z którymi przyszło im się zmagać. Szczególną troskę okazywali sprawom o charakterze społecznym, w tym trudnościom ekonomicznym związanym ze stosunkami własnościowymi, podziałem dóbr i pracą - uważając je za pewnego rodzaju fundament życia wspólnotowego ludzi. Jeśli zatem fundament będzie pełen wad - wadliwa również będzie cała struktura życia społecznego, w tym także państwo, jego władza i instytucje, edukacja, kultura, a wszystko to, co uważali za niesprawiedliwe i niemoralne $\mathrm{w}$ tych sferach ugruntowywało ich zdaniem - wadliwe, ale obowiązujące od wieków prawo. Powyższa konstrukcja myślowa, jak najbardziej odpowiadała marksistom i ich głównej tezie materializmu dialektycznego zakładającej przecież, że to byt kształtuje świadomość. Z kolei na gruncie materializmu historycznego - marksiści uważali, że „baza” i związane z nią stosunki własnościowe odpowiadają za

\footnotetext{
S. Drelich, Utopie jako nadzieja, op. cit., s. 15 i nast.

65 P.-F. Morreau, Le récit utopique. Droit naturel et roman de l'Etat, Paris 1982, s. 48-49.

66 Ibidem, s. 49.

67 Por. ibidem.
} 
„nadbudowę”, czyli inne niż ekonomiczne przejawy życia społecznego. Stanowiło to dla nich podstawę ich tzw. socjalizmu naukowego, odróżnianego od socjalizmu utopijnego ${ }^{68}$.

Warto przy tym zaznaczyć, że utopiści nie przedstawiali swoich światów bez żadnych wad i problemów. Przeciwnie, przedstawiali światy borykające się z identycznymi jak nasze problemami i wadami, z którymi w przeciwieństwie jednak do świata realnego - utopie - doskonale sobie potrafiły radzić - wszelkie społeczne problemy w zasadzie rozwiązując, a negatywne skutki, zazwyczaj indywidualnych ludzkich wad - minimalizując. Jak słusznie zauważyła Irena Pańków, utopijne projekty społeczeństwa doskonałego są ekspresją i dowodem na to, że możliwe jest unieważnienie zła, zaprzęgnięcie go w służbę dobra, czy skierowanie w nieszkodliwe obszary ${ }^{69}$. W ten sposób filozofia staje się siłą zdolną zmieniać rzeczywistość ${ }^{70}$. Problematyka utopii wiązała się ściśle $z$ wieloma działami filozofii, w tym przede wszystkim filozofii społecznej przez możliwości udoskonalania form życia zbiorowego ludzi i poprawiania ich ekonomicznego statusu. Na gruncie filozofii polityki wiązała się z koniecznością reorganizacji państwa i sprawowanej w nim władzy. Wreszcie w filozofii prawa, niemalże nakazywała odwoływanie się do prawa natury jako prawa doskonałego, gdyż najlepiej odzwierciedlającego społeczne poczucie sprawiedliwości.

Twórcy utopii czasów Oświecenia doskonale zdawali sobie z sprawę z tego, że tylko dzięki takiemu prawu, które będzie odwoływało się do porządku natury jego mądrości i sprawiedliwości, można zmieniać ten świat, czyniąc go rzeczywiście lepszym. Ów porządek natury „stanowić miał idealną normę życia, kryterium oceny stosunków społeczno-politycznych, podstawę programu przebudowy świata i ustanowienia nowego ładu"71.

W powyższym kontekście każdą zasadniczą, szybką, gwałtowną i trwałą zmianę systemu społecznego jako całości - wynikiem, której jest nowy system prawa, możemy - jak twierdzi Harold J. Berman nazwać rewolucją ${ }^{72}$. Według niego rewolucje mają "charakter «totalny», w tym mianowicie sensie, iż w ich wyniku nie tylko powstawały nowe systemy rządzenia, lecz także kształtowały się nowe struktury stosunków społecznych i gospodarczych, a także stosunków między państwem a Kościołem, nowe systemy prawa oraz nowe wizje społeczeństwa, nowe spojrzenie na historię, nowe wartości i przekonania"73. Można zatem powiedzieć, że podobnie „totalny” charakter miały francuskie utopie

68 Zob. M. Abensour, L'histoire de l'utopie et le destin de sa critique, Utopiques IV, Paris 2016, s. 79-107.

69 I. Pańków, op. cit., s. 173.

70 Filozofię jako siłę zdolną zmieniać rzeczywistość - ujmował austriacki filozof Erich Heintel (19122000), o czym pisze: M. Szyszkowska, W poszukiwaniu sensu życia, Warszawa 1997, s. 206.

71 W. Parniewski, Szkice z dziejów myśli utopijnej (od Platona do Zinowjewa), Łódź 2000, s. 43.

72 H. J. Berman, Prawo i rewolucja. Kształtowanie się zachodniej tradycji prawnej, tłum. S. Amsterdamski, Warszawa 1995, s. 33.

73 Ibidem, s. 34. 
oświeceniowe, które zakładały, że za pomocą nowego prawa można uregulować we właściwy sposób praktycznie wszystko.

W powyższym kontekście daje się zauważyć pewnego rodzaju prawidłowość, mówiąca o tym, że utopie stanowią ideowe preludium do przyszłych rewolucji społecznych ${ }^{74}$. Za fakt historyczny uznajemy to, że utopie oświeceniowe poprzedzały wybuch rewolucji we Francji w 1789 r., podobnie jak XIX-wieczny socjalizm utopijny przyczynił się najpierw do powstania socjalizmu naukowego, który odegrał fundamentalną rolę ideologiczną podczas rewolucji październikowej w Rosji. Wszystkie utopie i rewolucje łączy przy tym nadzieja, że da się zorganizować lepsze niż dotychczas społeczeństwo, poprzez zmianę obowiązującego porządku prawnego ${ }^{75}$.

Taki charakter miała zatem rewolucja francuska, która doprowadziła do upadku monarchii absolutnej i dominującego od stuleci feudalnego porządku prawnego, wykorzystując do tego celu, teoretyczne siły utopii oraz praktyczne możliwości prawa do stworzenia nowego systemu społecznego, poprzez ustanowienie własnego prawa, odwołującego się do przesłania intelektualnego zawartego w utopiach ${ }^{76}$. Z utopijnego punktu widzenia ze zmianą rewolucyjną prawa, wiązano szczęście ludzi, sprawiedliwość i rozwój państwa socjalnego. W rzeczywistości rewolucja, często wbrew intencjom utopistów, a nawet samych rewolucjonistów niesie ze sobą chyba zbyt wiele ludzkich nieszczęść, niesprawiedliwość oraz związany z przemocą terror, za którym co najgorsze stoją: nowe prawo (w postaci stanowionej) i nowe, pod względem rozwiązań ustrojowych - państwo (władza) ${ }^{77}$. Trudno zaprzeczyć temu, że rewolucja francuska, co podkreślał Jan Baszkiewicz, kojarzy się z krwią ${ }^{78}$. Według niego jednak każda rewolucja wiąże się ściśle z kulturą polityczną, która ,jest zjawiskiem długiego trwania (...) cechuje ją plastyczność: ulega ona presji wydarzeń, zwłaszcza tak potężnych jak rewolucja społeczna. Nie jest wszakże gąbczasta, nie wchłania wszystkiego, cym się ją nasyca. Nie ma zresztą i nie było nigdy rewolucji, która by zaczynała od zera"79.

$74 \quad$ Por. J. Russ, Le Socialisme utopique français, Paris 1988, s. 7.

75 Por. J.-C. Martin, Révolution française, [w:] Dictionnaire critique de l'utopie au temps des Lumières, op. cit., s. 1117-1135.

76 Por. E. J. Gay, Eugen Dühring and Post-Utopian Socialism, [w:] The State as Utopias: Continental Approaches, red. J. G. Backhaus, New York - Dordrecht - Heidelberg - London 2011, s. 194.

77 Por. J. Rambaud, Histoire des doctrines économiques, Paris - Lyon 1899, s. 399 i nast.

78 J. Baszkiewicz, Rewolucja francuska 1789-1794. Społeczeństwo obywatelskie, Warszawa 1983, s. 287.

79 Idem, Ciagłość i zmiana w kulturze politycznej okresu rewolucji: przykład Rewolucji francuskiej, [w:] idem, Państwo. Rewolucja. Kultura polityczna, Poznań 2009, s. 683 


\section{Wnioski}

Jakże trafnie poglądy jednego z XVIII-wiecznych utopistów francuskich Gabriela Bonnot de Mably określił w swojej monografii na jego temat Marek Blaszke wskazując, że w sensie doktrynalnym da się je ulokować gdzieś między utopią a reformą ${ }^{80}$. Podobnie można spróbować podsumować myśl innych francuskich utopistów tamtych czasów, których poglądy rozciągają się między utopią z jednej strony, a czymś o podłożu bardziej realnym, z drugiej strony, co wiązać należy z określoną doktryną polityczno-prawną. W powyższym kontekście poglądy Jana Meslier da się rozłożyć między utopią a rewolucją, poglądy Etienna G. Morelly między utopią a kodyfikacją, poglądy Ludwika S. Mercier'a między utopią a państwem liberalnym, poglądy Brissot'a de Warwille'a między utopią a sprawiedliwością, poglądy Dom Deschamps'a między utopią a praworządnością, poglądy Mikołaja E. Rectifa de la Bretonne'a między utopią a republiką, a poglądy Jana Jakuba Rousseau między utopią a demokracją (bezpośrednią), czy może suwerennością (ludu).

W powyższym kontekście tworzenie utopii staje się jedynie teoretycznym, czyli ideowym punktem wyjścia do przeobrażeń świata realnego. Wydaje się, że wszystkie poglądy przedrewolucyjne podważające, zwłaszcza stary porządek prawny, krytykujące go i postulujące jego zmianę, można ująć jako znajdujące się gdzieś między utopią a nową rzeczywistością. Rzeczywistością, którą będzie można wykreować opierając się na ideałach, do których się odwoływano oraz nowe prawo stanowione a oparte na prawie natury, które będzie je utrwalało. Wśród przedrewolucyjnych ideałów, do których odwoływali się utopiści, na pierwszym miejscu należy wymienić niezbywalne i uniwersalne prawa natury: wolności i równości ludzi uznawanych za obywateli, mających wpływać nie tylko na swoje indywidualne losy, ale także losy wspólnoty, którą tworzą, czyli społeczeństwa oraz państwa. Następnie w ich utopiach są również takie ideały, jak chociażby: konstytucjonalizm, republikanizm, podział władz, utylitaryzm, państwo laickie, państwo prawne, ochrona praw człowieka, czy sprawiedliwość społeczna. Powyższe wartości eksponowane niegdyś przez utopistów są dzisiaj zakorzenione w obowiązującym prawie większości demokratycznych państw prawa, stanowiąc ideowe podstawy ich funkcjonowania. Praktyka polityczna i historia XX-wiecznych totalitaryzmów pokazuje, że obecnie najniebezpieczniejsze może okazać się to, że wartości te pozostaną jedynie tradycyjnymi zapisami w obowiązującym prawie, których nikt nie będzie przestrzegał, nie dlatego, że nie chce, ale dlatego, że w świecie realnym nie da się ich przestrzegać. Jedyną wartością propagowaną przez wspomnianych francuskich utopistów, a wciąż odrzucaną przez systemy prawne większości państw świata, jest konieczność zniesienia własności prywatnej jako podstawy funkcjonowania

80 Por. M. Blaszke, Mably. Między utopia a reformą, Wrocław - Warszawa - Kraków - Gdańsk - Łódź 1985, s. 6 i nast. 
gospodarki (neo)-liberalnej i jej globalnej dominacji. Niniejsze poglądy na temat własności prywatnej uznaje się za komunizujące i nadal pozostające społeczną utopią.

\section{Bibliografia}

Abensour M., L'histoire de l'utopie et le destin de sa critique, Utopiques IV, Paris 2016.

Allemand R.-M., L'utopie, Paris 2005.

Baczko B., Jak wyjść z Terroru, tłum. W. Dłuski, Gdańsk 2005.

Baczko, Lumières de l'Utopie, Paris 1978.

Baczko B., Światła utopii, tłum. W. Dłuski, Warszawa 2016.

Baczko B., Wyobrażenia społeczne. Szkice o nadziei i pamięci zbiorowej, tłum. M. Kowalska, Warszawa 1994.

Baszkiewicz J., Historia Francji, Wrocław - Warszawa - Kraków 2004.

Baszkiewicz J., Państwo. Rewolucja. Kultura polityczna, Poznań 2009.

Baszkiewicz J., Rewolucja francuska 1789-1794. Społeczeństwo obywatelskie, Warszawa 1983.

Baszkiewicz J., Wolność. Rówwność. Własność. Rewolucje burżuazyjne, Warszawa 1981.

Baszkiewicz J., Ryszka F., Historia doktryn politycznych i prawnych, Warszawa 1979.

Berman H. J., Prawo i rewolucja. Kształtowanie się zachodniej tradycji prawnej, tłum. S. Amsterdamski, Warszawa 1995.

Blaszke M., Mably. Między utopia a reforma, Wrocław - Warszawa - Kraków - Gdańsk - Łódź 1985.

Bougainville L. A., Podróż Bougainville'a dookoła świata, tłum. L. Szwykowski, M. Szwykowska, Warszawa 1962.

Condorcet A. N., Szkic obrazu postępu ducha ludzkiego poprzez dzieje, tłum. B. Suchodolski, Kraków 1957.

Desroche H., Baczko (Bronislaw): Lumières de l'Utopie, „Archives de Sciences Sociales des Religions" 1979, nr 47/2.

Dictionnaire critique de l'utopie au temps des Lumières, red. B. Baczko, M. Porret, F. Rosset, Chêne-Bourg 2016.

Dictionnaire des utopies, red. M. Riot-Sarcey, T. Bouchet, A. Picon, Paris 2002.

Drelich S., Utopie jako nadzieja. Najważniejsze założenia koncepcji utopijnych starożytności i odrodzenia, „Dialogi Polityczne” 2003, nr 1.

Farrugia G., Qu'écrire sur le bonheur au XVIIIe siècle après Robert Mauzi? [w:] Le bonheur au XVIIIe siècle, red. G. Farrugia, M. Delon, Rennes 2015.

Filozofia francuskiego Oświecenia. Wybrane teksty z historii filozofii, wyboru dokonał oraz wstępem i przypisami opatrzył B. Baczko, Warszawa 1961. 
Gay E. J., Eugen Dühring and Post-Utopian Socialism, [w:] The State as Utopias: Continental Approaches, red. J. G. Backhaus, New York - Dordrecht - Heidelberg - London 2011.

Hervada J., Prawo naturalne. Wprowadzenie, tłum. A. Dorabialska, Kraków 2011.

Kuźmicz K., Utopia jako metoda filozofowania o społeczeństwie, państwie, prawie. Krótka analiza badawcza, [w:] Myślenie o polityce i prawie. Przedmiot, metoda, praktyka, red. I. Barwicka-Tylek, A. Czarnecka, M. Jaskólski, J. Malczewski, Warszawa 2015.

Le Flamanc A., Les utopies prérévolutionnaires et la philosophie du 18e siècle, Paris 1934.

Leś M. M., Fantastyka socjologiczna, Poetyka i myślenie utopijne, Białystok 2008.

Lichtenberger A., Le socialisme utopique: études sur quelques précurseurs inconnus du socialisme, Genève 1978.

Mably, Zasady praw, tłum. J. Hochfeld, t. 1-2, Kraków 1952.

Mandeville B., Bajki o pszczołach, tłum. A. Glinczanka, Warszawa 1957.

Meslier J., Testament, tłum. Z. Bieńkowski, Kraków 1955.

Monteskiusz, Listy perskie, tłum. T. Żeleński-Boy, Warszawa 1979.

Molnar T., L'Utopie: éternelle hérésie, tłum. z ang. O. Launay, Paris 1967.

Morabito M., Bourmaud D., Historia konstytucyjna i polityczna Francji (1789-1958), tłum. A. Jamróz, Białystok 1996.

Moreau P.-F., Le récit utopique. Droit naturel et roman de l'Etat, Paris 1982.

Morelly, Kodeks natury czyli prawdziwy duch jej praw, tłum. D. Malewska, Kraków 1953.

Pańków I., Filozofia utopii, Warszawa 1990.

Parniewski W., Szkice z dziejów myśli utopijnej (od Platona do Zinowjewa), Łódź 2000.

Perroy É., Doucet R., Latreille A., Historia Francji, t. 1: Od początku dziejów do roku 1774, tłum. A. Łochocka, Warszawa 1969.

Rambaud J., Histoire des doctrines économiques, Paris-Lyon 1899.

Réau L., L'Europe française au siècle des lumières, Paris 1971.

Rihs Ch., Les philosophes utopistes: le mythe de la cité communautaire en France au XVIIIe siècle, Paris 1970.

Rousseau J.J., Nowa Heloiza, tłum. E. Rzadkowska, Wrocław 1962.

Russ J., Le Socialisme utopique français, Paris 1988.

Ruyer R., L'Utopie et les utopies, Paris 1950.

Seidler G. L., Przedmarksowska myśl polityczna, Kraków 1974, 1985.

Stefaniak Ł., Utopizm: źródła myślowe i konsekwencje cywilizacyjne, Lublin 2011.

Swift J., Podróże Guliwera, oprac. z ang. C. Niewiadomska, Warszawa 1995.

Szyszkowska M., W poszukiwaniu sensu życia, Warszawa 1997.

Świętochowski A., Utopie w rozwoju historycznym, Warszawa 1910.

Tatarkiewicz W., O szczęściu, Warszawa 2010. 
Tokarczyk R., Paradygmat utopizmu w zmaganiach z paradygmatem realizmu, [w:] Oblicza utopii, obłudy i zakłamania I, red. W. Łysiak, Poznań 2013.

Wolter, Kandyd, czyli Optymizm, tłum. T. Żeleński-Boy, Warszawa 1961.

Wołodkiewicz W., Uwagi na temat prawoznawstwa w filozofii wieku Oświecenia, [w:] Filozofia Marii Szyszkowskiej. Księga dedykowana, red. A. Kryniecka, Białystok 2012.

Zdybel L., Malarczyk J., Historia doktryn polityczno-prawnych, Lublin 2001. 